\title{
EVALUATION OF RESEARCH METHODOLOGY WORKSHOP FOR POSTGRADUATES IN A MEDICAL COLLEGE, TIRUPATI
}

\author{
G. Ravi Prabhu1, B. Srihari Rao², M. S. Sridhar ${ }^{3}$, K. Ashok Kumar Reddy ${ }^{4}$ PAS Chandrasekharan ${ }^{5}$, D. Shankara Reddy ${ }^{6}$, A. S. Kireeti ${ }^{7}$ \\ 1Professor \& HOD, Department of Community Medicine, ACSR Govt. Medical College, Nellore. \\ 2 Professor, Department of General Surgery and Medical Education Coordinator, SV Medical College, Tirupati. \\ ${ }^{3}$ Professor, Department of General Medicine and Prinicipal, SV Medical College, Tirupati. \\ ${ }^{4}$ Professor \& HOD, Department of Community Medicine, SV Medical College, Tirupati. \\ 5 Professor, Department of Obstetrics \& Gynaecolony, SV Medical College, Tirupati. \\ ${ }^{6}$ Assistant Professor, Department of Community Medicine, SV Medical College, Tirupati. \\ ${ }^{7}$ Associate Professor, Department of Paediatrics, SV Medical College, Tirupati.
}

\begin{abstract}
BACKGROUND: Dissertation writing and research has become mandatory for all the postgraduate students. As per the University norms, a postgraduate student has to undertake a research study and submit dissertation as per the rules and regulations. This present study aims to find out the improvement in the knowledge level of the first year postgraduate students in research methodology as assessed by pretest and posttest evaluations.

MATERIALS AND METHODS: This cross-sectional study was done on research methodology workshops conducted during 2-4 September 2015 at SV Medical College, Tirupati. The improvement in the awareness levels was tested by pretest and posttest. Participant evaluation of the programme and feedback was also collected. The evaluation of the sessions was done using Median and 25-75 percentile grading. The grades converted into a numerical percentage and average grade $\%$ was calculated. A probability value of less than 0.05 was considered as statistically significant.

RESULTS: The mean pretest score of 3.32 significantly improved to 10.53 in the posttest. The improvement was found to be relatively high with regard to reference writing (93\%), type of referencing (88\%), entering data on excel (78\%), objectives (75\%) and framing a title (72\%). The quality of the sessions was graded being good for all topics while some topics were graded as being excellent. Overall, all the topics had achieved a minimum mean percentage grade of $70 \%$ while reference writing guidelines, discussion writing and ethical issues in research had scored higher relative grade.

CONCLUSIONS: There is a need to improve the format of the workshop for addressing the needs of the postgraduates in dissertation work. The sessions should be short with higher emphasis in improving the skills in dissertation writing rather than improving their awareness level.
\end{abstract}

KEYWORDS: Dissertation Work, Research Methodology, Pretest, Posttest, Awareness Levels, Postgraduates, Medical College.

HOW TO CITE THIS ARTICLE: G. Ravi Prabhu, B. Srihari Rao, M. S. Sridhar, K. Ashok Kumar Reddy, PAS Chandrasekharan, D. Shankara Reddy, A. S. Kireeti. "Evaluation of Research Methodology Workshop for Postgraduates in A Medical College, Tirupati." Journal of Evolution of Medical and Dental Sciences 2015; Vol. 4, Issue 93, November 19; Page: 15868-15872,

DOI: $10.14260 /$ jemds/2015/2303.

INTRODUCTION: Dissertation writing and research has become mandatory for all the postgraduate students. As per the University norms, a postgraduate student has to undertake a research study and submit dissertation as per the rules and regulations. ${ }^{(1)}$ The health research training is a fundamental and essential component in medical education.(2) It is a well-known fact that a formal training in research methods is not part of the undergraduate medical curriculum in India in contrast to other professions. Research methodology training has remained a neglected area in the Indian curriculum of medical education.(3) Hence a postgraduate student of medicine is completely new to

Financial or Other, Competing Interest: None.

Submission 03-11-2015, Peer Review 04-11-2015,

Acceptance 11-11-2015, Published 18-11-2015.

Corresponding Author:

Dr. G. Ravi Prabhu

Professor \& HOD,

Department of Community Medicine,

ACSR Govt. Medical College,

Nellore-524004.

E-mail: raviprabhu1610@gmail.com

DOI:10.14260/jemds/2015/2303. research and is not expected to follow the proper guidelines of research.

The reasons for this neglect of research methodology training are many and include the lack of funding and trained manpower resulting in vicious cycle of poor research productivity.(4) Giri et al (5) has found that the major obstacles for research included lack of time due to vast curriculum (59.5\%), lack of research curriculum $(25.0 \%)$ and inadequate facilities for research (25.8\%). Sumi et al(6) has also found that too much paperwork was the most frequently cited obstacle in conducting clinical research followed by lack of time.

Medical Council of India has stressed the need for a formal training in research methodology within the first six months of the postgraduate course.(7) In order to encourage and improve the research experience among postgraduates, Medical Council of India has made mandatory to attend not only one national/international conference but also give a oral/poster presentation and send the article for publication. Research methodology workshop for first year postgraduates is being conducted regularly every year in most of the medical colleges. 
This workshop is expected to provide the needed knowledge to choose the research topic, submit the protocol of their dissertations and subsequently conduct the research work and submit dissertation to the University concerned. This present study aims to find out the improvement in the knowledge level of the first year postgraduate students in research methodology as assessed by pretest and posttest evaluations. At the same time, the participant evaluation of the sessions and feedback were also collected. This workshop is expected to provide the organizers of such workshops in other institutions regarding the topics to be focused upon and help them in the proper conduct of the workshops.

METHODOLOGY: This cross-sectional study was done on research methodology workshops conducted during 2-4 September 2015 at SV Medical College, Tirupati. The format of the workshop has been changed (Compared to previous years) in order to provide scope for lively interaction among the participants and faculty for a better understanding of the concept of research methodology in medical research. On each day of the workshop, there were 30 participants who were made into 5 batches of 6 students each. The workshop consisted of 7 sessions incorporating the various elements of research methodology.

At the beginning of each session, the resource person concerned gave a brief overview of the topic in less than 20 minutes. It was ensured that the lecture was lively one with frequent questions and clarifications. This was followed by group discussion exercise with each group presenting their group work with discussion among the participants facilitated by the resource person. Each group sat around a round table during the time of discussion while for the brief lectures by the resource persons, the participants adjusted themselves for listening to the lecture.

On each day, the session began with a pre-test incorporating 12 questions covering several areas of research methodology. The expected answers were very short to be written in the space provided at the end of each question. Maximum time given for pre-test was 15 minutes. The student is expected to write his/her name and department. At the end of the workshop, all participants were given post-test paper (with same questions as in the pre-test) with same time of 15 minutes.

A separate questionnaire for evaluation was given to grade the sessions of the workshop from a scale of 1-5 with 1-excellent; 2-good; 3-average; 4-below average; 5-poor. The participant is expected to write the code for that grade. In the evaluation form, arrangement of food, venue and audiovisual aids was also assessed with the same codes. The participants were also instructed to write general feedback on the workshop with suggestions for the improvement of the workshop.

In order to facilitate the unbiased feedback, the participants are instructed not to enter their identification details like name, department etc., in the evaluation form. The data was entered into MS excel software and later analyzed using the Epiinfo software 7.0 version. The differences in the mean scores of pretest and post-test was analyzed using paired student's test.
The evaluation of the sessions was done using median and 25-75 percentile grading. The grades converted into a numerical percentage and average grade $\%$ was calculated. A probability value of less than 0.05 was considered as statistically significant.

RESULTS: In all, there were 91 participants belonging to various departments. Table 1 shows the mean score in the pre-test and post-test (With a maximum score of 12).

\begin{tabular}{|c|c|c|c|}
\hline $\begin{array}{c}\text { Type of } \\
\text { Test }\end{array}$ & $\begin{array}{c}\text { Number of } \\
\text { Participants }\end{array}$ & $\begin{array}{c}\text { Mean } \\
\text { Score }\end{array}$ & $\begin{array}{c}\text { SD } \\
\text { Score }\end{array}$ \\
\hline Pretest & 91 & 3.32 & 2.05 \\
\hline Post test & 91 & 10.53 & 1.52 \\
\hline \multicolumn{3}{|c|}{ Table 1: Pre-Test and Post-Test Mean } \\
Scores of Participants \\
\hline
\end{tabular}

$\mathrm{t}=29.3 ; \mathrm{P}<0.001 ; \mathrm{S}$

It can be seen that the mean score of 3.32 in the pre-test improved to 10.53 in the post-test after the workshop. The difference was found to be statistically significant $(\mathrm{P}<0.001$; S). Hence, one can say that the workshop has significantly improved the awareness level of the participants.

Table 2 shows the improvement in the correct responses to questions pertaining to various topics after the workshop (Post-test) compared to before the workshop (Pre-test).

\begin{tabular}{|c|c|c|c|c|}
\hline $\begin{array}{l}\text { Sl. } \\
\text { No }\end{array}$ & $\begin{array}{l}\text { Question } \\
\text { Pertaining } \\
\text { to Topic }\end{array}$ & $\begin{array}{c}\text { Correct } \\
\text { Response } \\
\text { in Pre- } \\
\text { test (\%) }\end{array}$ & $\begin{array}{l}\text { Correct } \\
\text { Response } \\
\text { in Post- } \\
\text { test (\%) }\end{array}$ & $\begin{array}{c}\text { Improvement } \\
\text { (\%) }\end{array}$ \\
\hline 1 & Framing title & 13 & 85 & 72 \\
\hline 2 & Objectives & 22 & 97 & 75 \\
\hline 3 & $\begin{array}{l}\text { Review of } \\
\text { literature }\end{array}$ & 5 & 74 & 69 \\
\hline 4 & Study design & 7 & 59 & 52 \\
\hline 5 & $\begin{array}{l}\text { Sampling } \\
\text { technique }\end{array}$ & 46 & 87 & 41 \\
\hline 6 & Sample size & 71 & 98 & 27 \\
\hline 7 & $\begin{array}{l}\text { Entering data } \\
\text { in excel }\end{array}$ & 12 & 90 & 78 \\
\hline 8 & $\begin{array}{c}\text { Test of } \\
\text { statistical } \\
\text { significance - } \\
1\end{array}$ & 45 & 96 & 51 \\
\hline 9 & $\begin{array}{c}\text { Test of } \\
\text { statistical } \\
\text { significance - } \\
2\end{array}$ & 30 & 96 & 66 \\
\hline 10 & Pie-diagram & 18 & 53 & 35 \\
\hline 11 & $\begin{array}{c}\text { Type of } \\
\text { referencing }\end{array}$ & 8 & 96 & 88 \\
\hline 12 & $\begin{array}{l}\text { Reference } \\
\text { writing }\end{array}$ & 4 & 97 & 93 \\
\hline \multicolumn{5}{|c|}{$\begin{array}{c}\text { Table 2: Pre-Test and Post-Test Correct Responses } \\
\text { to Questions on Various Topics. }\end{array}$} \\
\hline
\end{tabular}




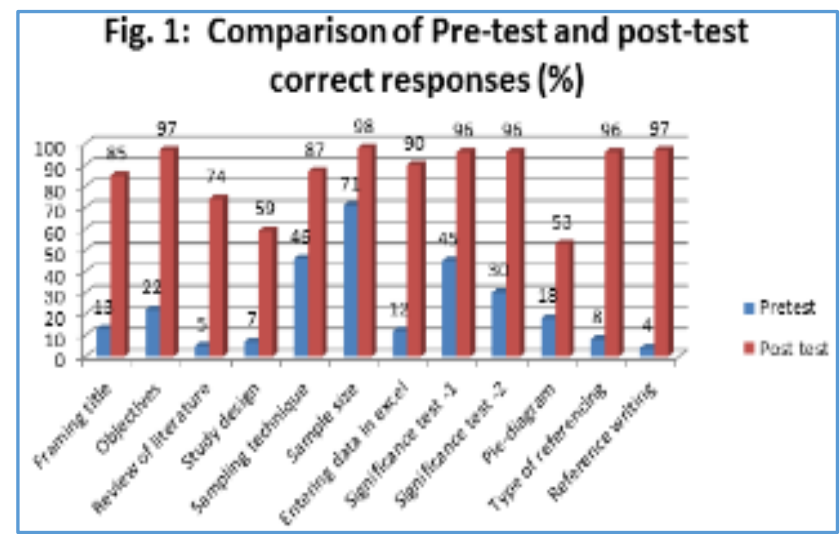

Thus in the pre-test, low performance (less than 35\% correct response) was found with regard to referencing, review of literature, study design, framing title, entering data on excel, objectives, pie diagram, tests of statistical significance etc., In the post-test, it was found that correct response was found to be more than $70 \%$ in all questions. It may be noted that the improvement was found to be relatively high with regard to reference writing (93\%), type of referencing (88\%), entering data on excel (78\%), objectives (75\%) and framing a title (72\%). Thus the awareness levels of the participants on various topics significantly improved with workshop.

\begin{tabular}{|c|c|c|}
\hline $\begin{array}{c}\text { Sl. } \\
\text { No. }\end{array}$ & $\begin{array}{c}\text { Name of the } \\
\text { Session }\end{array}$ & $\begin{array}{c}\text { Grading- Median } \\
(\mathbf{2 5 - 7 5} \text { Percentile) }\end{array}$ \\
\hline 1 & Title, aim, objectives & Good (Good-excellent) \\
\hline 2 & $\begin{array}{c}\text { Review of literature, } \\
\text { methodology }\end{array}$ & Good (Good-excellent) \\
\hline 3 & Sampling techniques & Good (Good-excellent) \\
\hline 4 & $\begin{array}{c}\text { Ethical issues in medical } \\
\text { dissertations }\end{array}$ & $\begin{array}{c}\text { Excellent (Good- } \\
\text { excellent) }\end{array}$ \\
\hline 5 & $\begin{array}{c}\text { Basic methods of statistical } \\
\text { analysis }\end{array}$ & Good (Good-excellent) \\
\hline 6 & $\begin{array}{c}\text { Discussion writing in } \\
\text { dissertation }\end{array}$ & $\begin{array}{c}\text { Excellent (Good- } \\
\text { excellent) }\end{array}$ \\
\hline 7 & $\begin{array}{c}\text { Reference wiring } \\
\text { guidelines }\end{array}$ & $\begin{array}{c}\text { Excellent (Good- } \\
\text { excellent) }\end{array}$ \\
\hline \multicolumn{3}{|c|}{ Table 3: Grading of the Sessions } \\
\hline
\end{tabular}

Thus all the sessions had a median grade of 'good,' while the sessions on ethical issues in medical research, discussion writing and reference writing had achieved a median grade of being 'excellent' by the participants. Hence, the quality of the sessions is highly satisfactory and the organizers have fulfilled their expectations in making the workshop successful. For better appreciation and relative grading, the following conversion is made and the mean percentage score was calculated.

Excellent-85\%;

Good- 70\%;

Average-50\%;

Below average-35\%;

Poor-20\%
The following table shows the percentage grade after such conversion:

\begin{tabular}{|c|c|c|}
\hline $\begin{array}{c}\text { Sl. } \\
\text { No. }\end{array}$ & $\begin{array}{c}\text { Name of the } \\
\text { Session }\end{array}$ & $\begin{array}{c}\text { Mean } \\
\text { Percentage } \\
\text { Grading }\end{array}$ \\
\hline 1 & Title, aim, objectives & 76 \\
\hline 2 & Review of literature, methodology & 73 \\
\hline 3 & Sampling techniques & 74 \\
\hline 4 & $\begin{array}{c}\text { Ethical issues in medical } \\
\text { dissertations }\end{array}$ & 77 \\
\hline 5 & Basic methods of statistical analysis & 74 \\
\hline 6 & Discussion writing in dissertation & 77 \\
\hline 7 & Reference wiring guidelines & 78 \\
\hline \multicolumn{2}{|c|}{ Table 4: Mean Percentage Grading of the Sessions } \\
\hline \multicolumn{2}{|c}{} \\
\hline
\end{tabular}

Thus reference writing guidelines, discussion writing and ethical issues in research had scored higher relative grade. Overall, all the topics had achieved a minimum mean percentage grade of $70 \%$, which speaks about the success of the sessions organized.

The venue of the workshop was graded as either excellent or good by a large proportion of participants (96\%). The audiovisual aids was graded as excellent/good by $76 \%$, while the food was graded excellent/good by $72 \%$ participants.

Almost all students had felt the workshop was useful and beneficial. Many of them have appreciated the efforts taken by the Principal, Medical coordinator and other resource persons for spending their valuable time in organizing this workshop for the participants. Many felt that sessions were interactive and facilitators had empowered them on many aspects of dissertation work. Many have felt that the workshop is invaluable for writing dissertation. Some participants suggested that there should be another workshop before the postgraduates submit their dissertation work to the University.

However, a few negative points and suggestions were made by the participants:

- Avoid academic confrontation among speakers which may lead to chaos and confusion among the participants. Only one resource person should act as facilitator in analyzing the group work.

- Conduct the workshop for two days (instead of a single day) for a better understanding.

- Too many things discussed; difficult to understand and memorize.

- Too lengthy sessions. Sessions extended beyond the time schedule of programme.

- There should be a break in between the sessions.

- Session timings are to be strictly adhered.

- Improve audiovisual arrangements for uninterrupted and undisturbed sessions.

- Ethical issues in research and reference writing to be more elaborately covered.

- Separate workshop/training for statistical analysis of data is required.

- The programme should be conducted within one month of joining course.

- Oversaturation of information in a single day. 
- Proforma for writing a protocol and for submission to ethical committee were not given.

- Guidelines for paper writing and poster presentation for conferences not covered.

- Guidelines for choosing the guide for dissertation not discussed.

DISCUSSION: The research methodology workshops conducted in this medical college had largely fulfilled the aim of improving the awareness levels of the participants on writing dissertation as part of their academic schedule. Before the workshop, the participants had a mean pre-test score of 3.32 which improved significantly to 10.53 at the end of the workshop. It was found that there was significant improvement with all questions, especially reference writing, entering data on excel, framing a proper title and writing objectives. This was also reflected in the evaluation of the sessions by the participants.

All sessions were graded as of being 'good,' while a few sessions scored 'excellent' grade. An evaluation study of basic research methodology workshop held at Nagpur by Thakre et al.(8) Found a significant improvement in the mean knowledge score after the workshop from $36.1 \%$ to $77.4 \%$ while the mean attitude score also significantly improved from $36.1 \%$ to $75.8 \%$ after the workshop. A similar study also found significant improvement in knowledge level after short-term intervention.(9) Pawar et al., study.(3) Reported a moderate level of knowledge towards health research. Similar result was reported by Vodopivic et al.(10)

Among first year Croatian medical students. Giri et al.(5) Has found that only $18.9 \%$ knew the definition of research hypothesis while $17.2 \%$ and $21.5 \%$ knew the full form of MEDLARS AND MEDLINE respectively. In the same study, it was found that as much as $70.7 \%$ were willing to participate in research methodology workshop. While in India, research activities are not mandatory part of undergraduate medical education curriculum, in many developed countries like for example, Germany, $28 \%$ of publications are done with the involvement of medical students.(11) Similarly in Croatia, 23\% of medical students are involved in research projects.(12)

The scope and spectrum of medical research has tremendously expanded. There are several difficulties and constraints related to ethical principles, patient safety, confidentiality and cost. It is worthwhile to go through a formal training programme in research methodology to improve capacity and competence to conduct meaningful research.(13) Experience in research is vital for improving the skills in searching literature, collection, analysis of data and report writing.(14)

There are a few limitations for this present research study. The pre-test/post-test is based upon a set of 12 questions with very short answers expected from the participants. It is not designed to test the practical skill acquired at the end of the workshop, except for reference writing question and selection of the proper diagram for representation of data, which only have an element of practice skill included in it. The evaluation of the sessions is based on grading given by the participants.

The conversion of grading into percentage grading is purely arbitrary and the differences in the score do not reflect the differences in the quality of the sessions. The participants are not only from various departments but also from various other colleges in the state. As most of the resource persons are known guides and teachers for some of the students, there may be biased view of the sessions while grading them. Despite these limitations, this study brings into focus the need for such workshops for the postgraduates of subsequent batches.

CONCLUSION: The workshop on research methodology for the first year postgraduates conducted at SV Medical College, Tirupati from 2 - 4 September 2015 has been successful in significantly improving the awareness level of the participants and expected to help them in writing their dissertation as per the guidelines.

There is a need to improve the format of the workshop for addressing the needs of the postgraduates in dissertation work. Another workshop for the same batch of postgraduates before they submit their dissertation work is recommended. The sessions should be short with higher emphasis in improving the skills in dissertation writing rather than improving their awareness level.

\section{REFERENCES:}

1. Postgraduate dissertation guidelines [Internet]. Vijayawada: Dr NTR University of Health Sciences; 2015 [cited 2015 Oct 16]. p. 1-9.

Available from: ntruhs.ap.nic.in

2. Scaria V. Whisking, Research into medical curriculum: The need to integrate medical education to meet the future challenges. Calicut Med J. 2004;2:e1.

3. Pawar DB, Gawde SR, Marathe PA. Awareness about medical research among resident doctors in a tertiary care hospital, a cross sectional survey. Perspect Clin Res. 2012;3(2):57-61.

4. Sadana R, D'Souza C, Hyder AA, Chowdhury AM. Importance of health research in South Asia. BMI 2004;328(7443):826-30.

5. Giri PA, Bangal VB, Phalke DB. Knowledge, attitude and practices towards medical research amongst postgraduate students of Pravara Institute of Medical Sciences University of Central India. J Fam Med Prim Care. 2014;3(1):22-4.

6. Sumi E, Murayama T, Yokode M. A survey of attitudes towards clinical research among physicians at Kyoto University Hospital. BMC Med Educ. 2009;9:75.

7. India Medical Council of India. Postgraduate medical education regulations 2000 (Amended upto May 2013). [Internet]. India; 2013 [cited 2015 Oct 16]. p. 3-6. Available from: http://www.mciindia.org/Rules-andRegulation/Postgraduate-Medical-Education-

Regulations-2000.pdf

8. Thakre SB, Thakre SS, Golawar SH, Ughade SN, Thakre AD. Awareness about biomedical research among postgraduate students at a tertiary care hospital, Central India: Pretest-posttest design. Prospect Med Res. 2014;2(2):8-14.

9. Khan H, Khwaja MR. Impact of a workshop on the knowledge and attitude of medical students regarding health research. J Coll Phys Surg Pak. 2007;17(1):59. 
10. Vodopivec I, Vujaklija A, Hrabak M, Lukic IK, Marusic A, Marusic M. Knowledge about and attitude towards science of first year medical students. Croat Med J. 2002;43(1):58-62.

11. Cursiefen C, Altunbas A. Contribution of medical student research to the medline indexed publications of a German faculty. Med Edu. 1998;32(4):439-40.
12. Kolcic I, Polasek O, Mihalj K, Gombac E, Kraljevic V, Kraljevic I. Research involvement speciality choice and emigration performances of final year medical students in Croatia. Croat Med J. 2005;46(1):88-95.

13. Jindal SK. Research in clinical sciences. Indian J Chest Dis Allied Sci. 2012;54(3):175-82.

14. Potti A, Mariani P, Saeed M, Smego RA. Jr residents as researchers: expectations, requirements and productivity. Am J Med. 2003;115:510-4. 